DOI:

\title{
Genetic options for combating biotic stresses in cool-season food legumes
}

\author{
Gemechu Keneni and Seid Ahmed ${ }^{1}$
}

Holetta Agricultural Research Center, Ethiopian Institute of Agricultural Research (EIAR), P. O. Box 2003, Addis Ababa, Ethiopia; ${ }^{1}$ International Center for Agricultural Research in the Dry Areas (ICARDA), B. P. 6299, Rabat, Morocco

(Received: November 2016; Revised: November 2016; Accepted: November 2016)

\begin{abstract}
Cool-season food legumes, mainly faba bean (Vicia faba), chickpea (Cicer arietinum), field pea (Pisum sativum), lentil (Lens culinaris) and grass pea (Lathyrus sativus), are economically and ecologically important crops in many countries. However, a number of biotic stresses (diseases, insects and parasitic weeds) constrain their productivity at farm level. Breeding efforts have been underway for many decades to address these biotic stresses at national and international levels. As the result a number of improved varieties are developed and released along with proper crop management and protection practices. Due to the appearances of new pathogen population; absence of resistance sources for pests in the cultigen for pests with wide host range and emerging pests, continued breeding efforts have been required to come up with new cultivars. Molecular markers have started playing a major role to facilitate deploying complex traits to adaptive cultivars background. The purpose of this review is, therefore, to shed light on research progresses and challenges in cool season food legume breeding to major diseases, insect pests and parasitic weeds.
\end{abstract}

Keywords: Biotic stresses, food legumes, resistance

\section{Introduction} breeding

World population is alarmingly increasing and food production should be increased but further expansion of cultivated area is not possible in many developing countries as cultivable land cannot be indefinitely increased (Borlaug 2000). Food and nutrition insecurity, therefore, become a serious concern because of the mismatch between demand and supply in many parts of the developing world, particularly in the tropics and the sub-tropics (Quinones et al. 1997; Sanchez 2002).
Agricultural productivity must be increased in environmentally friendly and sustainable ways in order to improve food availability thereby reverse the current situation where significant portions of the population in developing countries are food and nutrition insecure (Sanchez 2002).

Faba bean (Vicia faba), field pea (Pisum sativum), chickpea (Cicer arietinum), lentil (Lens culinaris) and grass pea (Lathyrus sativus) are among the strategic cool-season food legume crops playing key roles for food, incomes, animal feed and sustainable cereal production (Keneni and Imtiaz 2010). Despite global production on several tens of millions of hectares, the productivity of these crops have been low as compared to cereals due to their biological limitations, biotic stresses such as disease, insects and parasitic weeds (Seifi et al. 2013; Rubiales et al. 2015). Post-harvest losses due to storage pests is another challenge of these food legumes mainly in small holder farmers (Keneni et al. 2011).

The negative impacts of pests (diseases, insect pests and weeds) could be managed by several options (cultural, biological, physical and pesticides) including host plant resistance (Armes et al. 1996; Keneni et al. 2011). Breeding of productive and resistant genotypes to pests is considered as one of the best options to manage the key pests in many countries. The purpose of this review is, therefore, to shed light on research progresses and challenges in cool season food legume breeding to major diseases, insect pests and parasitic weeds with future prospects.

*Corresponding author's e-mail: gemechukeneni@yahoo.com

Published by the Indian Society of Genetics \& Plant Breeding, F2, First Floor, NASC Complex, PB\#11312, IARI, New Delhi 110012

Online management by indianjournals.com; www.icar.org.in 


\section{Major biotic stresses}

The major diseases of cool-season food legumes are Ascochyta blights (Ascochyta spp.); rusts (Uromyces spp.), chocolate spots (Botrytis spp.), wilt/root rots complex (Fusarium spp., Rhizoctonia bataticala, $R$. solani, Sclerotium rolfsii), powdery mildew (Erysiphe pisi), anthracnose (Colletotrichum truncatum), Stemphylium blight (Stemphylium botryosum), faba bean gall (Olpidium viciae), and different viruses (Rubiales et al. 2015). Field insects including black bean aphid (Aphis spp), African ball worm (Helicoverpa armigera), green pea aphid (Acrythosiphon pisum), cutworm (Agrotis spp) and leaf miner (Liriomyza cicerina) are among the major ones. The major storage insect pests are Callosobruchus and Bruchus spp. Food legumes are also affected by parasitic weeds (Orobanche and Phelipanche spp) in the Mediterranean region, Ethiopia and Sudan. Some diseases like Stemphylium blight on lentil, Botrytis gray mold ( $B$. cinerea) affecting chickpea and lentil are limited in South Asia. Moreover, leaf miner is a key insect pest in North Africa and west Asia causing $30-40 \%$ yield losses.

\section{Biotic stresses breeding philosophies}

In order to achieve improved resistance to pests in food legumes and other crops breeders follow different breeding philosophies (Sedgley 1991) including the following:

\section{Defect removal vis-a -vis recombination breeding}

Defect removal, as described by Donald (1968), involves elimination of specific limiting traits including susceptibility to biotic stresses. Defect removal may be the best strategy whenever it is the possibility not only in terms of time saving but also in terms of effectiveness and efficiency as one of the parents is already adapted. Breeding efforts to remove defects should, therefore, not go far away from the areas of past success but rather they should build on the past successes. It is simply the conversion of otherwise well adapted varieties for simply inherited traits like most of the insect pest resistance into their resistant/ desirable versions through incorporation of missing desirable genes using the backcross technique. For instance, breeders in Ethiopia have been following defect removal strategy to convert the otherwise welladapted faba bean varieties into their chocolate spot resistant versions by a backcrossing scheme. In this case, exotic materials with chocolate spot resistance but not adaptable have been crossed with the local adapted materials that lacked resistance to the disease. A number of resistant varieties have been released this way (Keneni et al. 2016). This approach is common for breeding simply inherited traits including biotic stress resistance but less common for improving polygenic traits (Singh 2002).

The application of recombination breeding may also need the best parents to pre-exist for best-is-bybest recombination. If best parents do not pre-exist, starting breeding works just from the scratch to develop such parents may take a longer time and/or ultimately show lesser probability of success to generate good results. When the desirable characters are found distributed among many different genetic backgrounds, and a single genotype combining desirable attributes are of rare occurrence, a series of (multiple) crossing or (transgressive) recombination may be required in order to bring desirable traits distributed among multiple parents into a single genetic background for further selection among the progenies. For instance, incorporation of different resistance genes from different parents into a single genotype by gene pyramiding to control the different biotypes had been possible with the breeding of mungbean for multiple resistances to different biotypes of bruchids (Chen et al. 2007; Somta et al. 2007). Some specific defects of the final progeny may be removed through backcrossing.

\section{Direct vis-a-vis indirect selection}

Falconer (1989) suggested the concept of direct and indirect selection environments which was later applied in several investigations related to the determination of optimum selection environments for crops (Ceccarelli 1989; Ceccarelli and Grando 1996; Banziger and Lafitte 1997; Woldeyesus et al. 2002) including legumes (Keneni et al. 2001). Many studies showed the concept that cultivars selected under favourable environments would also suit to the unfavourable ones does not have sufficient scientific background (Ceccarelli 1989; Ceccarelli and Grando 1996; Banziger and Edmeades 1997; Banziger et al. 1997; Banziger and Lafitte 1997).

It is now clear that there is no purpose in breeding biotic stress resistant genotypes in stress free environments. Many of varieties developed under potential conditions have also failed to succeed under marginal conditions (Ceccarelli 1989; Reijntjes et al. 1992; Ceccarelli and Grando 1996) because it is practically impossible to collect together genes 
responsible for superior performance in all environments into a single genotype (Annicchiarico 2002). There are also some reports with compromising ideas as far as the concept of direct and indirect selection environments are considered. The use of "intermediate" environments as primary selection sites was suggested as a good alternative over either selection at high or low yielding environments (Allen et al. 1978), but there is no clear criterion to determine the intermediateness of a given environment. Testing of varieties under both stressed and non-stressed conditions could be one of the stable options to create alternative varieties that suit both conditions, but the cost of germplasm evaluation would obviously be greatly increased.

Experiences from breeding faba bean for waterlogged vertisols, where black root rot is a severe associated problem, showed that indirect selection under Broad Bed and Furrow (drained environment) may be useful to identify better genotypes for flatbed conditions (waterlogged environment), but the relative efficiency of indirect selection was lower than direct selection under the flatbeds themselves (Keneni et al. 2001). The same study showed that there was no need to evaluate genotypes under both the drained conditions of Broad Bed and Furrow and the undrained flatbeds.

\section{Empirical vis-a-vis analytical breeding approaches}

The analytical approach emanates from the concept that heritability and genetic variance of primary traits are typically lower under stress versus non-stress conditions (Rosielle and Hamblin 1981). As a result, direct selection for primary traits per se is often not sufficiently effective when these traits are more polygenic than their components (Lawes et al. 1983). The use of secondary traits positively associated with primary traits, genetically variable and highly heritable is advisable under such conditions (Lawes et al. 1983; Edmeades et al. 1998).

Despite lower heritability and genetic variance of polygenic primary traits under stress, it is assumed that heritability and genetic variation of some secondary traits may remain high and at the same time the traits may maintain good level of desirable association with primary traits. Nevertheless, most of the recent reports confirm that it is not sufficient for a breeder to identify secondary traits as determinants of primary traits but the relative efficiency of indirect selection for these determinants over selection for primary traits per se must be systematically quantified (Wricke and Weber 1986) including in legumes (Keneni and Jarso 2002). In chickpea, for instance, the efficiency of direct and indirect selection for yield was evaluated and indirect selection via pod number and seed weight was found to be more efficient than direct selection for yield itself (Kumar and Bahl 1992). Direct selection may also be difficult for biotic stress resistance in the early stages of segregating materials in breeding nurseries where the breeder is forced to select from thousands of individual plants on the basis of their phenotypic performance (Singh 2002) as exposing each and every segregant to stresses like storage insects is difficult. The genetic expression of different traits and the extent and pattern of their relationship with primary traits may also vary with changes in the environment (Rosielle and Harblin 1981; Hawtin 1982; Lawes et al. 1983), and some traits may become more influential to primary traits than others with changes in intensity and timing of the stress (Richards 1987).

\section{Ideotype vis-a-vis concept of component optimization}

The concept of ideotype breeding was first suggested by Donald (1968). Selection in this case is totally based on yield components (Smith 1987; Singh 2002) but only in some cases for biotic stress resistance. In chickpea, for instance, ideotypes suitable for winter sowing were suggested as Ascochyta blight resistant, cold tolerant, with a longer vegetative cycle and erect habit with bearing pods on upper parts of the branches to facilitate mechanical harvesting (Saccardo and Calcagno 1990). On the other hand, ideotypes for spring sowing were suggested to have a short vegetative cycle, good adaptability, high yield and good grain quality. Two lines each were selected as new cultivars in Italy for winter sowing ("Califfo" and "Sultano") and spring sowing ("Principe" and "Calia") (Saccardo and Calcagno 1990). Another study showed that chickpea ideotypes with fern leave were more resistant to Ascochyta blight than unifoliate-leafed ideotypes (Gan et al. 2003) despite the existence of conflicting reports indicating susceptibility to Ascochyta blight was not linked to multipinnate or simple leaf types but resistance to Ascochyta blight depended more on genetic background than leaf shape (Danehloueipour et al. 2008). Some reports also indicated that a large number of stomata per unit area of leaf, stem hairiness as well as a small number of tertiary branches are associated with Ascochyta blight resistance (Crino 1990). Spreading types of chickpea were found to be 
more susceptible to Helicoverpa damage than erect types, as were kabuli types compared to desi types (Yadav et al. 2006).

The desirability of a trait may be environment specific, and a common ideotype may not suit all environments (Saxsena and Sinha 1987) as the genetic expression of different traits and the extent and pattern of their relationship with primary traits normally vary with changes in the environment (Lawes et al. 1983). The traits to be considered in the ideotype breeding approach are generally morphological, physiological, biochemical, anatomical, phenological or their combinations (Singh 2002). While the theory of ideotype breeding itself is attractive, the required characterization of "model" components for the target environment has been difficult to achieve as different genotypes may give the same performance for the primary trait through different component pathways (Smith 1987).

\section{Why breeding for biotic stresses resistance/ tolerance?}

The use of resistant/tolerant varieties against biotic stresses provide a number of comparative advantages particularly as compared to environmental manipulation with agro-chemicals. Just to mention a few, agro-chemicals may be costly as they need to be repeatedly applied every season or even many times within a season. However, once cultivars resistant to pests become available, their use may involve no additional cost apart from the initial seed cost and seed based technologies are easier to transfer to farmers than more complex knowledge based agrochemical application (Edmeades et al. 1998). Price ratios between external inputs and farm outputs may also not allow the use of large quantities of pesticides in marginal areas (de Boef et al. 1996). Integrated pest management (IPM) requires a host with certain level of resistance as an important component (Panda and Khush 1995). Repeated use of pesticides may result in resurgence of target pests, development of insecticide resistance, outbreaks in secondary pests and reduction in population of natural enemies (Panda and Khush 1995). The harmful residual effects and food safety have also been issues of great concern with agro-chemicals. Principles of organic crop production also do not conflict with the use of host resistance (Keneni et al. 2011).

\section{Conceptual frameworks for breeding successes}

\section{Choice of germplasm}

Gains from selection largely depends, among others, on the magnitude of genetic variability available for the trait under consideration in the initial genetic material (Falconer 1989; Hayward and Breese 1993; Singh 2002). The source of genetic variability for biotic stress resistance mainly created by introduction of pre-known exotic germplasm, target collection of germplasm from local sources and crossing of parents extracted from both sources. Pest resistance may often be found not in commercial varieties but in old cultivars, landraces or wild relatives which may not be good for per se agronomic performance. Existence of good pest resistance in commercial cultivars would make life easier for breeders as commercial varieties have already desirable agronomic attributes for direct use in production without much genetic manipulation and modification (Acevedo and Fereres 1993; Singh 2002). Crossing genotypes from different sources was also found to be promising for breeding programs to increase pest resistance.

It is generally believed that landraces as sources of initial breeding materials have considerable breeding values under sub-optimal production as they contain valuable adaptive genes to different circumstances (Ceccarelli 1994; Bunder et al. 1996; Chahal and Gosal 2002; Provorov and Tikhonovich 2004). Effective pest resistance may be achieved from genetic improvement of the host but genes for complete resistance to field and storage insect pests may not exist in cultivated species of food legumes (Hossain 2009; Nadeem et al. 2011; Keneni et al. 2011) as opposed to wild relatives which have coexisted with pests on an evolutionary time scale (Acosta-Gallegos et al. 2008). Some reports showed improved varieties are more susceptible to insect pests than landraces (Desroches et al. 1995; Lale and Kolo 1998) because improvements associated with grain quality might have inadvertently resulted in more susceptibility of the improved cultivars as compared to local cultivars (Shaheen et al. 2006; Keneni et al. 2011).

Genetic recombination and selection of desirable segregants would be more successful as it goes from tertiary to primary gene pools. In a few cases, genes of biotic stresses may be located in wild relatives and successfully transferred to cultivated species. For instance, diverse resistance genes from the wild relatives of chickpea showing high levels of antibiosis 
to pod borer were suggested for introgression into cultivated chickpea as sources of resistance to this insect (Sharma et al. 2005). Similarly, two wild relatives of chickpea, namely C. echinospermum and C. reticulatum, were suggested as sources of resistance to Ascochyta blight as their hybrids were also found to resulted in fully fertile progenies (Collard et al. 2001).

In addition to primary, secondary or tertiary gene pools and their crosses, the advanced-level use of biotechnology for breeding resistant varieties to biotic stresses, particularly insect pests, include the transfer of the gene for resistance (cry gene) from a soil-born bacterium (Bacillus thuringiensis) into the cultivated crops like soybean (Bowman et al. 2003). Even though only cry genes from $B$. thuringiensis have been commercially exploited so far for this purpose, many other genes of plant origins have also been successfully used to confer resistance (Ranjekar et al. 2003; Keresa et al. 2008). For instance, the transfer of a gene for $\alpha$ amylase inhibitor-1 $(\alpha \mathrm{Al})$ from haricot bean to field pea was successful in effectively protecting the latter from pea weevil (B. pisorum) regardless of concerns for food safety (Prescott et al. 2005). Many such attempts for genetic transformation have been underway since the early 1990s in a number of pulses including field pea, haricot bean, chickpea, groundnut, lentil, pigeon pea, cow pea and faba bean (Shade et al. 1994; Morton et al. 2000; Ranjekar et al. 2003; Ignacimuthu and Prakash 2006; Keresa et al. 2008). Not only genetic transformation proper but also markerassisted selection has been effective for developing varieties resistant to biotic stresses in a number of food legumes (Roman et al. 2003; Chen et al. 2007; Zhao et al. 2008).

The development of legume varieties tolerant to herbicides through genetic manipulation of using traditional, mutational or transgenic technique was found to be an effective approach that allowed farmers to widely use herbicides to control weeds in crops like soybean and lentil (Tan and Bowe 2009). Steps to be followed in breeding for resistance/tolerance to biotic stresses with initial genetic materials from primary, secondary or tertiary gene pools is illustrated in detail elsewhere using storage insect pests as examples (Keneni et al. 2011).

\section{Characterization and evaluation of germplasm}

Characterization and evaluation of germplasm by genebanks mostly focus on morphological differentiation of accessions using qualitative traits that show little genotype by environment interaction (Carvalho 2004). However, for genetic evaluation to be useful, evaluation must be related to relevant characters like high yield, resistance to biotic stresses, adaptation to different environments and recommendation domains, fitness to farming system and improved quality. Although time-consuming and expensive, systematic evaluation for biotic stresses resistance/tolerance is necessary to best benefit from conserved germplasm (Carvalho 2004). Genetic characterization and evaluation of accessions is done based on descriptors (Carvalho 2004; de Vicente et al. 2005) and using molecular markers (Zhu 1996; Upadhyaya et al. 2008). Germplasm with special merits have been characteristically identified for resistance/ tolerance to a number of biotic stresses in crops like chickpea, pigeon pea and groundnut at ICRISAT (Dwivedi et al. 2009; Upadhyaya et al. 2011).

\section{Choice of selection environment}

Breeding should be made either on the target environment or the actual circumstances of a given target environment should be simulated on the station. Pest resistance breeding is a method of exposing breeding materials to uniform and high pest pressure in areas of their hot spot (foliar diseases, insect pests), creation of sick plots (for soil borne pathogens and parasitic weeds) and under controlled conditions for both foliar and soil-borne pathogens and parasitic weeds. As there is no purpose in breeding abiotic stress resistant genotypes in stress free environments, the same thing holds true for breeding biotic stress resistant genotypes.

Breeders use different methods of ensuring existence of uniform and high pest pressure for different pests. For faba bean diseases resistance breeding in Ethiopia, for instance, hotspot areas are used for rust, while sick plot method is used for black root rot by increasing the inoculum level of the soil every year. Unlike the above two methods, chocolate spot is screened under artificial foliar inoculation. This method is dependable to ensure the desired level of chocolate spot pressure in the nursery though expensive. Planting of highly susceptible varieties after few rows of test material is also used to develop the inoculum. After spraying spores suspension, water may be sprayed to increase the humidity in the nursery the next day. Particularly, in the dry period, water spray for 12 hours is necessary to insure good infection. Several other methods could be used to create biotic stressed environments. Examples are the "detached 
leaf assay", inoculation of seedling roots by deepening in diseases suspensions before transplanting, using insect vectors from susceptible varieties to infest healthy plants and rubbing leaves of diseased plants onto healthy plants after causing mechanical injury in healthy plants.

Plants can also be artificially infested with insects for screening resistant genotypes against the insects under consideration. Infestation may involve mass production of the insect pests in laboratory inoculation and infestation of the test crop with eggs, larvae or adults depending on specific situations (Panda and Khush 1995). To screen resistant genotypes to storage insects, for instance, the insects are usually mass reared in laboratories on a bulk of seeds of susceptible cultivars under ambient room temperature and relative humidity. Then unsexed adults are randomly selected and placed in the jars with the test genotypes.

For parasitic weeds, various in vitro techniques have been used to allow close observation of the germination, attachment and early development of parasitic weeds. Use of Petri dishes was suggested for mass screenings of legume genotypes against Orobanche. Plants are grown individually in Petri dishes with Orobanche seeds to study induction of germination and resistance to penetration. Plots can also be artificially inoculated by mixing parasite seeds with the crop seeds when sowing. The detailed procedures of creating stresses environments is beyond the scope of this article.

\section{Selection criteria for biotic stresses resistance}

For pest resistance, both direct and indirect selections maybe used by breeders. Selection applied on one character to improve another character is termed as indirect selection. A secondary trait to be selected as a selection criterion should be cheap and fast to measure, stable within measurement period and a good estimator of the primary traits before it is measured (Lawes et al. 1983).

Chickpea genotypes with dwarf stem, light color of pod coat, small seeds, lower density of pubescence, early maturity and low content of protein showed resistance to pod borer. Higher secretion of malic acid was also found to be associated with resistance to Ascochyta blight (Crino 1990). In another study, accumulation of phenols, phytoalexins and hydrolytic enzymes have been associated with host plant resistance to Ascochyta blight (Pande et al. 2005).
Morphologically, varieties with smooth, soft, and thin seed coats were found to be preferred for oviposition than those with rough, hard, wrinkled and somewhat spiny seed coats by pulse beetles (Ahmed et al. 1989; Shaheen et al. 2006). In faba bean, for instance, Desroches et al. (1995) found that the seed coat acted like a physical barrier for two bruchid species ( $C$. chinensis and C. maculatus) and only $45-58 \%$ of the neonate larvae perforated the seed coat and reached the cotyledons.

Selection could also be based on a molecular marker for indirect selection of genetically determinant traits including biotic stress resistance/tolerance. A number examples exist for field insect pest resistance (Zhao et al. 2008), diseases (Tullu et al. 1999; Roman et al. 2003) and parasitic weeds (Roman et al. 2002; Díaz-Ruiz et al. 2009) where molecular markers are used to make selections (Rubiales et al. 2015).

\section{Genetic basis of biotic stress resistance in food legumes}

The genetic control of resistance/tolerance to diseases, insect pests and parasitic weeds are monogenic, oligogenic, polygenic or cytoplasmic in their nature. The difference in modes of inheritance implicates that different breeding methods maybe followed in different cases. The basic selection methods (i.e., mass, bulk, pedigree and backcross methods, etc. or their modifications) may be applied depending on the mode of inheritance and the number of genes controlling resistance under a given condition. For instance, cytoplasmically inherited resistance may require the backcross method to transfer the cytoplasm from one parent into another, using the parent from which the cytoplasm is to be transferred as the female (Singh 2002). Conversion of well-adapted varieties into their resistant counterparts could be the first priority in achieving agronomically desirable varieties that are resistant to the pest under consideration within a short time.

\section{Mechanisms of biotic stress resistance}

A detailed description of plant immune system at molecular level is a wide topic beyond the scope of this article but generally the mechanisms that plants employ to overcome pests include resistance, escape and tolerance. In insects, resistance maybe associated with antixenosis (non-preference of insects to host plant), antibiotics (adverse effect of host plant on feeding insects), tolerance (ability of a variety to produce greater yield than susceptible variety at the 
same level of insect attack) and avoidance or escape (escape of a variety from insect attack due to earliness or cultivation in the season where insect population is very low) (Panda and Khush 1995). A resistant legume variety may have one, two or more of these mechanisms as reviewed by Ali (2002). Low germination, haustoria formation and developmental stimulant production has been identified as mechanisms of tolerance to parasitic weeds in legumes (Rubiales et al. 2009).

\section{Achievements of breeding for biotic stresses}

There are many success stories and impacts of cultivars with high levels of resistance to biotic stresses in improving production and productivity of food legume in many countries. Many food legume varieties developed and released with high yield and disease resistance are adopted and brought impacts in many countries (Erskine et al. 2011). In Ethiopia, Ascochyta blight and wilt root rot resistant kabuli chickpea, rust resistant lentil and black root rot tolerant faba bean are widely grown by farmers with double productivity. Stemphylium resistant lentil cultivars developed from ICARDA breeding program are released and adopted by farmers in Bangladesh and Nepal (Erskine et al. 2011). A number of faba bean varieties tolerant to Orobanche have been developed and released in a number of countries such as Spain (Cubero 1994), Egypt (Khalil et al. 1993; Saber et al. 1999) and recently in Ethiopia (Abebe et al. 2015; MANR 2016). However, no variety with complete resistance to key insect pests and parasitic weeds of food may be found so far.

For field insects, a number of varieties were found to be tolerant in a number of countries (Ali and Mohamed 2014). For storage insects, complete resistance may be of rare occurrence in nature but existence of complete resistance to adzuki bean beetle in different gene pools among the cultivated species of haricot bean, field pea, cowpea (Vigna unguiculata), black gram (Vigna mungo) and chickpea have been reported (Redden and McGuire 1983; Pacheco et al. 1994; Dongre et al. 1996; Goossens et al. 2000; Morton et al. 2000; Shaheen et al. 2006).

\section{Challenges of resistance breeding}

\section{Multiple pest resistance}

Food legumes are simultaneously attacked by many biotic/abiotic stresses and a crop cultivar developed for resistance to one stress may at the same time be faced with another stress. In faba bean, for example, black root rot closely occurs with waterlogging. We frequently found many diseases on the same crop together. While the breeding for a single stress itself is sufficient to complicate the task of plant breeding, it is rather worsened by the interaction with other associated stresses (Ceccarelli et al. 2004). In such cases, the breeder is required to incorporated different resistance genes into the same cultivar to control the different biotic stress. There are many attempts to develop multiple resistance to soil borne pathogen complex, foliar diseases, parasitic weeds and insect pests (Maalouf et al. 2016). Some progresses are made in developing wilt/root rot resistance in chickpea, lentil and faba bean in combination with foliar diseases like chocolate spot, rust and Ascochyta blight (Emeran et al. 2011; Villegas-Fernandez et al. 2011; Maalouf et al. 2016). Moreover, developing resistance germplasm for pests with wide host range was a great challenge in food legume breeding. It is also to be mentioned that genotypes improved for better traits like seed quality may inadvertently become to bests like storage insects (Keneni et al. 2011).

\section{Evolution of insect pests, pathogens and parasitic weeds}

The major challenges of breeding for resistance is the evolution of new pest populations that affect popular cultivars and sources of resistance as a result of selection, gene flow, recombination and other factors (Rubiales et al. 2015). Changes in pathogen populations affecting chickpea, lentil and faba bean are reported from different countries where popular cultivars were taken out of production (Tullu et al. 1999; Udupa and Baum 2003; Sharma et al. 2007). A study on geographically distinct populations of $C$. maculatus have repeatedly highlighted significant intra-specific variations in performance on resistant cowpeas (Appleby and Credland 2004). A few reports also exist that resistance has often been overcome by more virulent 'races' of parasitic Orobanche (Joel 2000). The driving forces for the development of new variants of pest are believed to be selection pressure due to large scale production of improved cultivars, existence of sexual reproduction in pathogens, change of climate and farming system. The lack of new sources for resistance limits the ability to cope with newly developing pest variants. These biotic constraints are not only affecting the welfare of small holder famers but also threaten genetic diversity of food legumes in some countries. A notable example of new disease is on faba bean caused by Olpidium viciae which is becoming important in Ethiopia (Abebe et al. 2015; 


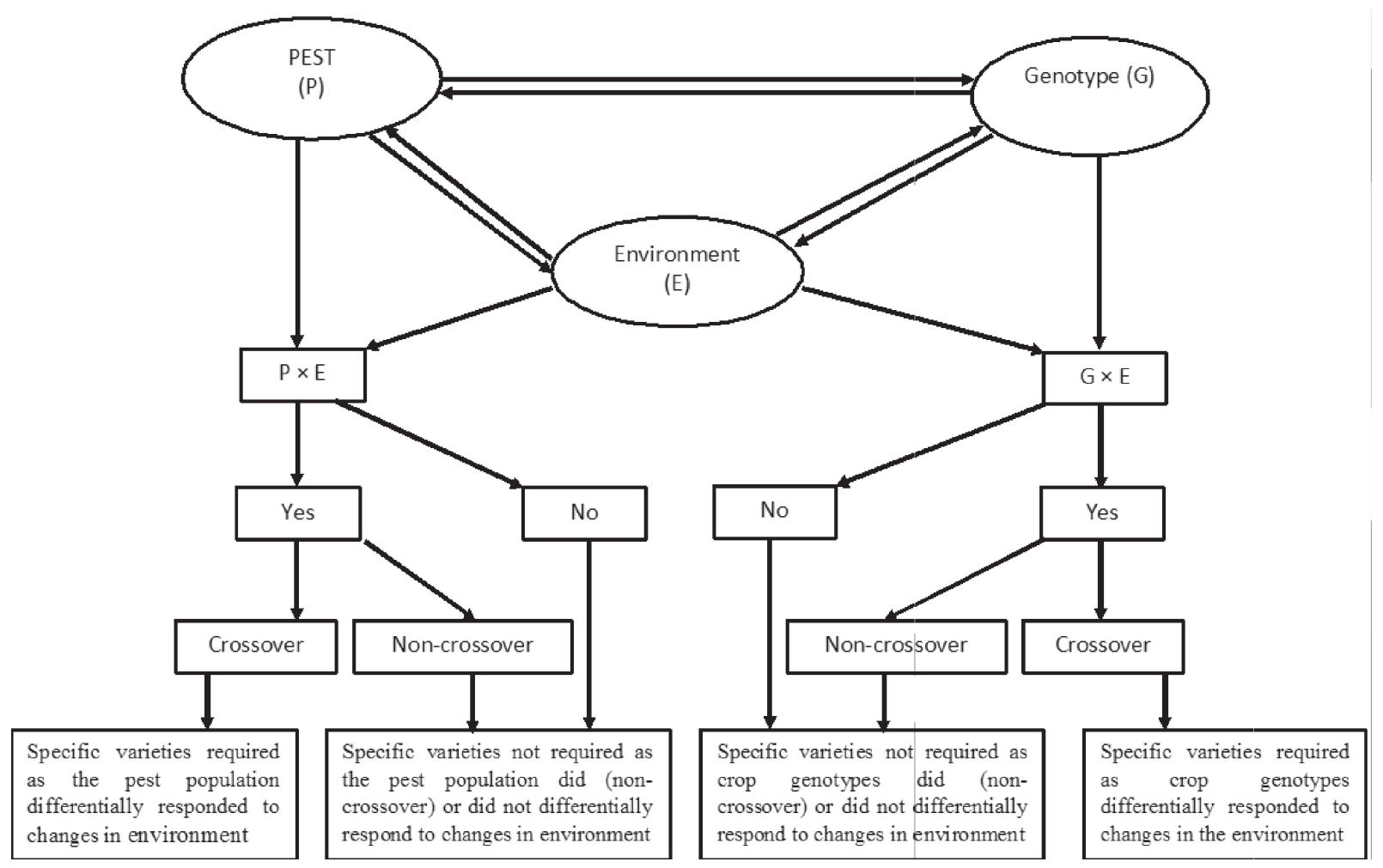

Fig. 1a. Schematic presentation of different breeding schemes when there is first order interaction between pest population and the environment and between crop genotypes and the environment showing complications due to the differential response of genotypes or pest population to changes in the environment

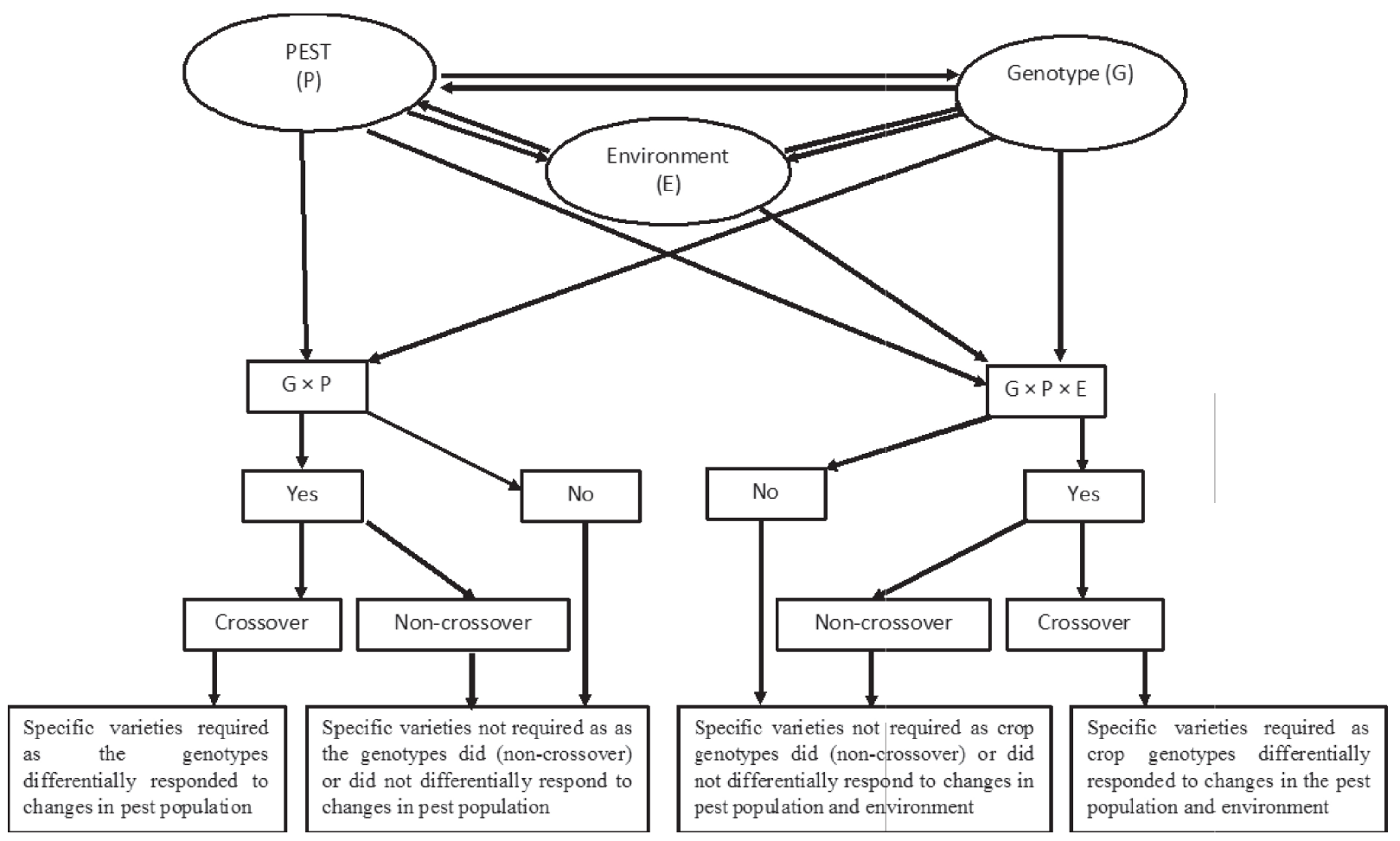

Fig. 1b. Schematic presentation of different breeding schemes when there is first and second order interaction between pest population and the environment and among crop genotypes, pest population and the environment showing complications due to the differential response of genotypes to changes in pest population to changes in the environment 
Keneni et al. 2016). Parasitic weeds on food legumes is expanding its ecology in East Africa and many farmers have stopped producing cool season food legumes in Ethiopia. Similarly, pea weevil (B. pisorum) is affecting field pea production.

The existence of complex host variant by pest variant by environment interaction complicated the breeding task. Varieties developed for resistance/ tolerance to one variant of pest, i.e. race of a pathogen, biotype of an insect species and "race" of a parasitic weed species, may not repeat the same level of resistance/tolerance to another race of the same pathogen/parasitic weed species and biotype of an insect species (Figures $1 \mathrm{a}$ and $\mathrm{b}$ ). Note that legumes are more liable to high genotype by environment interaction (Hawtin et al. 1988) as they contribute a significant amount of extra energy not only for yield but also for protein and/or fat formation and symbiotic nitrogen fixation (Keyser and Li 1992; Lindemann and Glover 2003). Variant of each pest species may differ in their ability to infest or attack varieties of the same host species. Cultivars resistant to one of such variants may fail to resist another variant and it will be challenging for plant breeders to develop cultivars that can universally resist all possible combination of variants. It is practically difficult to collect together genes for resistance/tolerance to all variants of a pest in all environments into a single genotype (Annicchiarico 2002) but a number of breeding efforts resulted in resistant genotypes of legumes crops to different races of diseases are reported in chickpea (Chen et al. 2004).

\section{Undesirable genetic linkage and lack of inter- specific cross-compatibility}

Linkage between biotic stress resistance, poor agronomic performance and anti-nutritional factors has been among technical challenges of significant concern in breeding food legumes (Edwards and Singh 2006; Keneni et al. 2011). In faba bean, chocolate spot resistance was found to be characteristically associated with very late flowering and maturity even if there is no solid evidence that the two traits are genetically linked (Gnanasambandam et al. 2012). We also observed similar phenomenon in Ethiopia. Many reports confirmed that proper exploitation of biotic stress resistance particularly in wild relatives is limited by the existence of undesirable genetic linkages (Edwards and Singh 2006; Acosta-Gallegos et al. 2008; Keneni et al. 2011) that reduce the quality of the produce or may even make it unfit for consumption
(Tomooka et al. 2000; Singh 2002; Chen et al. 2007; Somta et al. 2007).

The transfer of genes governing pest resistance from wild relatives to cultivated varieties presents interspecific cross-incompatibility (Singh 2002; Keneni et al. 2011). Examples of very low cross compatibility are many but, to mention a few, between Vigna umbellata and the adzuki bean ( $V$. angularis) and between $V$. radiata var. sublobata and $V$. mungo var. silvestris (Somta et al. 2006). Even if crosses are compatible, there may result in failure of zygotic formation (Singh 2002) and seed setting (Singh 2002; Keneni et al. 2011). Very low cross compatibility was also reported between Vigna umbellata and the adzuki bean ( $V$. angularis) and between $V$. radiata var. sublobata and $V$. mungo var. silvestris (Somta et al. 2006). The use of third compatible species as a bridge to cross two incompatible species is suggested (Somta et al. 2006) but not commonly applied in practice. For example, species of the $V$. minima, $V$. riukiuensis and $V$. nakashimae have been suggested as the most suitable bridging species between $V$. umbellata and $V$. angularis to transfer bruchid resistance from $V$. umbellata to $V$. angularis (Tomooka et al., 2000). Failure of seed setting in inter-specific crosses may also be overcome by the use of embryo culture techniques (Singh 2002).

\section{Limited knowledge of genetic bases of resistance}

It is almost established that resistance breeding provides sustainable solution to biotic stresses. However, the available basic information on genetics of resistance including modes of inheritance are not consistent and, when available, values of heritability and genetic gain from selection are low (Kogan 1982). There are also limited methods of bioassays and biochemical tests that the breeder has to employ to identify resistance in each and every segregant plant. Researchers in developing countries have lack of experience and new sources of resistance/tolerance to some biotic stresses like field and storage insects, newly introduced threats like the faba bean gall and Orobanche. It is unfortunate that the generation of basic information related to genetics of resistance to biotic stresses has received little attention compared to applied research.

Molecular techniques have a lot of technical limitations as, for instance, efficient methods of introducing foreign genes into desirable genotypes are still lacking (Romeis et al. 2004). The lack of an efficient 
protocol for the regeneration of transgenic plants was the main obstacle to transformation of some of these legumes (Gnanasambandam et al. 2012). When transformation is successful in terms of transferring resistance genes, food safety maybe become a concern as observed for storage insects in field pea and chickpea (Romeis et al. 2004; Sarmah et al. 2004; Prescott et al. 2005).

\section{Future prospective and conclusions}

Breeding legume crops for resistance to pests is likely to be successful as a number of studies demonstrated the existence of genetic variation in landraces, cultivated varieties and their wild relatives. Results showing resistance to diseases, insects and parasitic weeds are available from literature in many countries. Resistances are sometimes monogenic and transferring such resistance genes to commercial cultivars would be possible even with the conventional breeding approaches. Our understanding of the signaling mechanisms and the pest-host interaction is also growing with time.

In conclusion, past efforts made in biotic stress resistant/tolerant legume cultivars and in generation of the associated baseline scientific information, should not be undermined. However, the problems of biotic stresses facing highland food legumes have mostly been addressed using the conventional plant breeding tools. In relation to the desire, however, it is hardly possible to say that this approach has enabled us to overcome the problems as desired mainly because of limitations in making some major advances. The efforts to use cutting-edge biotechnological tools which support conventional plant breeding need to be strengthened particularly in developing countries. This would enable not only to further understand of the scientific bases of biotic stress resistance but also to combine resistance genes in a number of parents into a single genotype and to reduce breeding cycles. The use of QTL based markerassisted selection for biotic stress resistance breeding has recently shown promise in a number of crops (Rubiales et al. 2009; Gnanasambandam et al. 2012).

Developing effective techniques of phenotyping biotic stress resistance/tolerance is highly essential for success in legume. The efficiency of breeding under uncontrolled field condition versus controlled field condition, the critical stages of exposure of crops to the biotic stresses under different scenarios and the interaction of the biotic stresses with the host genotypes and the physical environments should also be taken into consideration in formulation of efficient techniques. The phenotyping techniques should not only enable to develop resistant varieties but also in a way that prevents the development of new variants of the causative agents of biotic stresses in the in future.

\section{Declaration}

The authors declare no conflict of interest.

\section{References}

Abebe T., Nega Y., Mehari M., Mesele A., Workineh A. and Beyene H. 2015. Genotype by environment interaction of some faba bean genotypes under diverse broomrape environments of Tigray, Ethiopia. J. Plant Breed. Crop Sci., 7: 79-86

Acevedo E. and Fereres E. 1993. Resistance to abiotic stresses. In: Plant Breeding: Principles and Prospects, pp 406-421, Hayward, M.D., Bosemark, N.O. and Romagosa, I., eds.). Chapman and Hall, Great Britain.

Acosta-Gallegos J. A., Kelly J. D. and Gepts P. 2008. Prebreeding in common bean and use of genetic diversity from wild germplasm. Crop Sci., 48: 3-16.

Ahmed K., Khalique F., Afzal M., Tahir M. and Malik B. A. 1989. Variability in chickpea (C. arietinum L.) genotypes for resistance to Callosobruchus maculates F. (Bruchidae). J. Stored Prod. Res., 25: 91-99

Ali K. 2002. An integrated approach to pest management in field pea (Pisum stativum L.) with emphasis on pea aphid (Acyrthosiphon pisum). PhD Dissertation, Faculty of Natural and Agricultural Sciences, University of Free State, Bloemfontein, South Africa

Ali A. E. and Mohamed A. A. 2014. Evaluation of Different Chickpea Genotypes for Resistance Against Pod Borer, Helicoverpa armiger (Hub.) (Lepdoptera: Noctuidae) under Field Conditions, Sudan. Persian Gulf Crop Protection, 3: 25-29

Allen F. L., Comstock R. E. and Rasmuddon D. C. 1978. Optimal environments for yield testing. Crop Sci., 8: 747-751.

Annicchiarico P. 2002. Genotype 9 environment interaction:challenges and opportunities for plant breeding and cultivar recommendation. FAO Plant Production and Protection Paper No. 174. Food and Agriculture Organization, Rome.

Appleby J. H. and Credland P. F. 2004. Environmental conditions affect the response of West African Callosobruchus maculatus (Coleoptera: Bruchidae) populations to susceptible and resistant cowpeas. J. Stored Prod. Res., 40: 269-287.

Armes N. J., Jadhava D. R. and Desouza K. R. 1996. A 
survey of insecticide resistance in Helicoverpa armigera in Indian subcontinent. Bull. Entomological Res., 86: 499-514.

Banziger M. and Edmeades G. O. 1997. Predicted productivity gains from breeding maize under stressed vs. non-stressed conditions. In: J.K. Ransom, A.F.E. Palmer, B.T. Zambezi, Z.O. Mduruma, S.R. Waddington, K.V. Pixley \& D.C. Jewell (Eds.), Maize Productivity Gains Through Research and Technology Dissemination, pp. 136-140. Proc 5th Eastern and Southern Africa Regional Maize Conference, held in Arusha, Tanzania, 3-7 June 1996. Addis Abeba, Ethiopia: CIMMYT.

Banziger M. and Lafitte H. R. 1997. Breeding for N-stressed environments: How useful are N-stressed selection environments and secondary traits? In: G.O. Edmeades, M. Banzinger, H.R. Mickelson \& C.B. Pena-Valdivia (Eds.), Deveolping Drought and Low $\mathrm{N}$-Tolerant Maize, pp. 401-404. Proc Symp,March 25-29, 1996, CIMMYT, El Batan, Mexico. Mexico D.F., CIMMYT

Banziger M., Betran F. J. and Lafitte H. R. 1997. Efficiency of high nitrogen selection environments for improving maize for low nitrogen target environments. Crop Sci., 37: 1103-1109.

Borlaug N. E. 2000. The green revolution revised and the road ahead. Special 30th anniversary lecture, The Norwegian Nobel Institute, Oslo.

Bowman D. T., May O. L. and Creech J. B. 2003. Genetic uniformity of the U.S. upland cotton since the introduction of transgenic cottons. Crop Sci., 43: 515518.

Bunder J., Loeber A., Broers J. E. W. and Havertkort B. 1996. An integrated approach to biotechnology development. In: Bunders J., Haverkort B. and Hiemstra W. (eds.). Biotechnology: building on farmers. Knowledge. Macmillan, London and Basingstoke, pp 201-227.

Carvalho M. A. 2004. Germplasm characterization of Arachis pintoi Krap. and Greg. (Leguminosae). PhD Thesis, University of Florida, USA.

Ceccarelli S. and Grando S. 1996. Importance of specific adaptation in breeding for marginal conditions. In: Gebre H. and Van Leur J. (eds.). Barley research in ethiopia: past work and future prospects. Proceedings of the 1st barley research review workshop, 16-19 Oct 1993, Addis Ababa: IAT/ ICARDA. Addis Ababa, Ethiopia, pp 34-58.

Ceccarelli S., Grando S., Baun M. and Udupa S. M. 2004. Breeding for drought resistance in a changing climate. In: Challenges and strategies for dryland agriculture. CSSA Special Publication No. 32, USA, Crop Science Society of America and American Society of Agronomy, pp 167-190.

Ceccarelli S. 1989. Wide adaptation: how wide? Euphytica,
40: $197-205$.

Ceccarelli S. 1994. Specific adaptation and breeding for marginal conditions. Euphytica, 77: 205-219.

Chahal G. S. and Gosal S. S. 2002. Principles and procedures of plant breeding: biotechnological and conventional approaches. Narosa Publishing House, New Delhi.

Chen W., Coyne C. J., Peever T. L. and Muehlbauer F. J. 2004. Blackwell Publishing, Ltd.

Characterization of chickpea differentials for pathogenicity assay of Ascochyta blight and identification of chickpea accessions resistant to Didymella rabiei. Plant Pathology, 53: 759-769.

Chen H. M., Liv C. A., Kuo C. G., Chien C. M., Sun H. C., Huang C. C., Lin Y. C. and Ku H. M. 2007. Development of molecular marker for a bruchid (Callosobruchus chinensis) resistance gene in mungbean. Euphytica, 157: 113-122.

Coffman W. R. and Smith M. E. 1991. Roles of public, industry and international research center programs in developing germplasm for sustainable agriculture. In: Plant Breeding and Sustainable Agriculture: Consideration for Objectives and Methods, pp. 1-9, Sleper D. A., Baker T. C. Bramel-Cox P. J. and Francis C. A. (eds). Proc. Symp. in Las Vegas, CSSA Publication No. 18, Crop Science Society of America, Madison.

Collard B. C. Y., Ade P. K., Pang E .C. K., Brouwer J. B. and Taylor P. W. J. 2001. Prospecting for sources of resistance to ascochyta blight in wild Cicer species. Australasian Plant Pathol., 30: 271-276.

Crino P. 1990. Chickpea breeding for resistance to ascochyta blight. CIHEAM - Options Mediterraneennes, 9: 55-60.

Danehloueipour N., Clarke H. J., Yan G., Khan T. N. and Siddique K. H. M. 2008. Leaf type is not associated with ascochyta blight disease in chickpea (Cicer arietinum L.). Euphytica, 162: 281-289.

De Boef W. S., Berg T. and Haverkort B. 1996. Crop Genetic Resources. In Biotechnology: Building on Farmers' Knowledge; Bunders, J., Haverkort, B., Hiemstra, W., Eds.; Macmillan: London, UK. pp. 103-128.

de Vicente M. C., Guzmán F. A., Engels J. and Rao V. R. 2005. Genetic characterization and its use in decision making for the conservation of crop germplasm: The role of biotechnology. In: International Workshop the Role of Biotechnology for the Characterization and Conservation of Crop, Forestry, Animal and Fishery Genetic Resources, pp 121-128, FAO, FOBIOTECH, ECOGENE, SIGA. Turin, Italy, 5-7 March 2005.

Desroches P., Elshazly E., Mandon N., Duc G. and Huignard J. 1995. Development of Callosobruchus chinensis (L.) and C. maculatus (F.) (Coleoptera: Bruchidae) L. in seeds of Vicia faba differing in tannin, 
convicine and vicine Contents. J. Stored Prod. Res., 31: 83-89.

Díaz-Ruiz R., Torres A., Gutierrez M. V., Rubiales D., Cubero J. I., Kharrat M., Satovic Z. and Román B. 2009. Mapping of quantitative trait loci controlling Orobanche foetida Poir. resistance in faba bean (Vicia faba L.). African J. Biotechnol., 8: 2718-2724.

Donald C. M. 1968. The breeding of plant ideotypes. Euphytica, 17: 385-403.

Edmeades G. O., Bolanos J., Banziger M., Ribaut J. M., White J. W., Reynolds M. P. and Lafitte H. R. 1998. Improving crop yields under water deficits in the tropics. In Crop Productivity and SustainabilityShaping the Future, Proceedings of the 2nd International Crop Science Congress, New Delhi, India, 14-17 November 1996; Chopra, V.L., Singh, R.B., Varma, A., Eds.; Oxford and IBH: New Delhi, India. pp. 437-451.

Edwards O. and Singh K. B. 2006. Resistance to insect pests: What do legumes have to offer? Euphytica, 147: 273-285.

Emeran A. A., Flores F. and Rubiales D. 2011. Multipledisease resistance in Vicia faba: multi-environment field testing for identification of combined resistance to rust and chocolate spot. Field Crop Res., 124: 5965.

Erskine W., Sarker A. and Kumar S. 2011. Crops that feed the world: Investing in lentil improvement toward a food secure world. Food Security, 3: 127-139.

Falconer D. S. 1989. Introduction to Quantitative Genetics, 3rd ed.; Longman: London, UK.

Gan Y., Liu P. and McDonald C. 2003. Severity of ascochyta blight in relation to leaf type in chickpea. Crop Sci., 43: 2291-2294.

Gnanasambandam A., Paull J., Torres A., Kaur S., Leonforte T., Li H., Zong X., Yang T. and Materne M. 2012. Impact of Molecular Technologies on Faba Bean (Vicia faba L.) Breeding Strategies. Agronomy, 2: $132-166$.

Hanounik S. B. and Robertson L. D. 1989. Resistance in Vicia faba germplasm to blight caused by Ascochyta fabae. Plant Dis., 73: 202-205.

Hawtin G. C., Muehlbauer F. J., Slinkard A. E. and Singh K. B. 1988. Current status of cool season food legume crop improvement: assessment of critical needs. In: Summerfield R. J. (ed.). World crops: cool season food legumes. Kluwer Academic Publishers, The Netherlands, pp 67-80.

Hawtin G. C. 1982. The genetic improvement of faba bean. In: G. Hawtin \& C. Webb (Eds.), Faba Bean Improvement, pp. 15-32. Proc faba bean Conf held in Cairo, Egypt, March 7-11, 1981. Martinus Nijhoff Publishers, The Netherlands.

Hayward H. D. and Breese E. L. 1993. Population structure and variability. In: Plant Breeding: Principles and Prospects, pp. 16-29, (Hayward, M.D., Bosemark, N.O. and Romagosa, I., eds). Chapman and Hall, Great Britain.

Hossain M. A. 2009. Field screening of chickpea genotypes against pod borer. Bangladesh J. Agril. Res., 34: 517-521.

Ignacimuthu S. and Prakash S. 2006. Agrobacteriummediated transformation of chickpea with á-amylase inhibitor gene for insect resistance. J. Biol. Sci., 31: 339-345.

Joel D. M. 2000. The long-term approach to parasitic weeds control: manipulation of specific

developmental mechanisms of the parasite. Crop Protect. 19: 753-758.

Keneni G. and Imtiaz M. 2010. Demand-driven breeding of food legumes for plant-nutrient relations in the tropics and the sub-tropics: Serving the farmers; not the crops! Euphytica, 175: 267-282.

Keneni G. and Jarso M. 2002. Comparison of three secondary traits as determinants of grain yield in faba bean on waterlogged Vertisols. J. Genet. Breed., 56: 317-326.

Keneni G., Asmamaw B. and Jarso M. 2001. Efficiency of drained selection environment for improving grain yield in faba bean under undrained target environments on Vertisol. Euphytica, 122: 279-285.

Keneni G., Bekele E., Getu E., Imtiaz M., Damte T., Mulatu B. and Dagne K. 2011. Breeding food legumes for resistance to storage insect pests: Potential and limitations. Sustainability, 3: 1399-1415.

Keneni G., Fikre A. and Eshete M. 2016. Reflections on Highland Pulses Improvement Research in Ethiopia: Past Achievements and Future Direction. Ethiopian Journal of Agricultural Sciences (EIAR 50th Year Jubilee Anniversary Special Issue): 17-50.

Keresa S., Grdisa M., Baric M., Baric J. I. and Marchetti S. 2008. Transgenic plants expressing insect resistance genes. Sjemenarstvo, 25: 139-153.

Keyser H. H. and Li F. 1992. Potential for increasing biological nitrogen fixation in soybean. Plant Soil, 141: $119-135$

Kharbanda P. D. and Bernier C. C. 1980. Cultural and pathogenic variability among isolates of Ascochyta fabae. Can. J. Plant Pathol., 2: 139-142.

Kogan M. 1982. Plant Resistance in Pest Management. In Introduction to Insect Pest Management, 2nd ed.; John Willey \& Sons: New York, NY, USA. pp. 93134.

Kumar J. and Bahl P. N. 1992. Direct and indirect selection for yield in chickpea. Euphytica, 60: 197-199.

Lale N. E. S. and Kolo A. A. 1998. Susceptibility of eight genetically improved local cultivars of cowpea to 
Callosobruchus maculatus F. (Coleoptera: Bruchidae) in Nigeria. Int. J. Pest Man., 44: 25-27.

Lawes D. A., Bond D. A. and Poulsen M. H. 1983. Classification, Origin, Breeding Methods and Objectives. In The Faba Bean (Vicia faba L.); Hebblethwaite, P.D., Ed.; The Cambridge University Press: Cambridge, UK. pp. 23-76.

Lindemann W. C. and Glover C. R. 2003. Nitrogen Fixation by Legumes. Cooperative Extension Service, College of Agriculture and Home Economics. New Mexico State University, Mexico.

Maalouf F., Ahmed S., Shaaban K. and Bassam B. ?. Fawzi Nawar, Murari Singh, Ahmed Amri. 2016. New faba bean germplasm with multiple resistances to Ascochyta blight, chocolate spot and rust diseases. Euphytica, 211: 157-167.

Ministry of Agriculture and Natural Resources (MANR). 2016. Crop variety register, Issue No. 18, Plant Variety Release, Protection and Seed Quarantine Control Directorate, MANR, Addis Ababa, Ethiopia.

Morton R. L., Schroeder H. E., Bateman K. S., Chrispeels M. J., Armstrong E. and Higgins T. J. V. 2000. Bean á-amylase inhibitor 1 in transgenic peas (Pisum sativum) provides complete protection from pea weevil (Bruchus pisorum) under field conditions. Proc. Natl. Acad. Sci. USA, 97: 3820-3825.

Muehlbauer F. J. and Singh K. B. 1987. Genetic of chickpea. pp 99-125 In M.C. Saxena and K. B. Singh (eds.). The Chickpea. CAB International, Wallingford, UK.

Nadeem S., Hamed M., Shafique M., Atta B. M. and Shah T. M. 2011. Evaluation for resistance in Kabuli chickpea genotypes against chickpea pod borer, Helicoverpa armigera (Hübner) (Lepidoptera: Noctuidae) under field conditions. Songklanakarin J. Sci. Technol., 33: 291-294.

Panda N. and Khush G. S. 1995. Host Plant Resistance to Insects. CAB International in association with International Rice Research Institute (IRRI): Biddles Ltd.: Guildford, UK.

Pande S., Siddique K. H. M., Kishore G. K., Bayaa B., Gaur P. M., Gowda C. L. L., Bretag T. W. and Crouch J. H. 2005. Ascochyte blight of chickpea (Cicer arietinum L.): A review of biology, pathogenicity and diseases management. Aust. J. Agric. Res., 56: 317-332.

Prescott V. E., Campbell P. M., Moore A., Mattes J., Rothenberg M. E., Foster P. S., Higgins T. J. V. and Hogan S. P. 2005. Transgenic expression of bean áamylase inhibitor in peas results in altered structure and immunogenicity. J. Agric. Food Chem., 53: 90239030.

Provorov N. A. and Tikhonovich I. A. 2004. Genetic resources for improving nitrogen fixation in legumerhizobia symbiosis. Genetic Resources and Crop Evol,, 50: 89-99.
Quinones M. A., Borlaug N. E. and Dowswell C. R. 1997. A fertilizerbased green revolution for Africa. In: Replenishing soil fertility in Africa. SSSA Special Publication No 51. Agronomy and Soil Science Society of America, 677 S. Segoe Rd., Madison, WI, 53711, USA, pp 81-95.

Ranjekar P. K., Patankar A., Gupta V., Bhatnagar R., Bentur J. and Kumar P. A. 203. Genetic engineering of crop plants for insect resistance. Curr. Sci., 84: 321-329.

Reijntjes C., Haverkort B. and Waters-Bayer A. 1992. Farming for the future: an introduction to low-externalinput and sustainable agriculture. Macmillan, London.

Richards R. A. 1987. Physiology and the breeding of winter-grown cereals for dry areas. In: Drought Tolerance in Winter Cereals, pp. 171-190, (Srivastana, J.P., Porceddu, E., Acevedo, E. and Varma, S., eds). Proceedings of an international workshop 27-31 Oct. 1985, Capri, Italy.

Román B., Torres A. M., Rubiales D., Cubero J. I. and Satovic Z. 2002. Mapping of quantitative trait loci controlling broomrape (Orobanche crenata Forsk.) resistance in faba bean (Vicia faba L.). Genome, 45: 1057-1063.

Román B., Satovic Z., Avila C. M., Rubiales D., Moreno M. T. and Torres A. M. 2003. Locating genes associated with Ascochyta fabae resistance in Vicia faba L. Aust. J. Agric. Res., 54: 85-90.

Romeis J., Sharma H. C., Sharma K. K., Das S. and Sarmah B. K. 2004. The potential of transgenic chickpeas for pest control and possible effects on non-target arthropods. Crop Prot., 23: 923-938.

Rosielle A. A. and Hamblin J. 1981. Theoretical aspects of selection for yield in stress and non-stress environments. Crop Sci., 21: 943-946.

Rubiales D., Fondevilla S., Chen W., Gentzbittel L., Higgins T. J. V., Castillejo M. A., Singh K. B. and Rispail N. 2015. Achievements and Challenges in Legume Breeding for Pest and Disease Resistance. Critical Reviews in Plant Sciences, 34: 1-42.

Rubiales D., Verkleij J. and Vurro M. 2009. Parasitic plant management in sustainable agriculture. Weed Res., 49: $1-5$

Saccardo F. and Calcagno. F. 1990. Consideration of chickpea plant ideotypes for spring and winter sowing. CIHEAM - Options Mediterraneennes, 9: 35-41.

Sanchez P. A. 2002. Soil fertility and hunger in Africa. Science, 295: 2019-2020.

Sarmah B. K., Moore A., Tate W., Molvig L., Morton R. L., Rees D. P., Chiaiese P., Chrispeels M. J., Tabe L. M. and Higgins T. J. V. (2004). Transgenic chickpea seeds expressing high levels of a bean a-amylase Inhibitor. Mol. Breed., 14: 73-82.

Saxsena M. C. and Sinha S. K. 1987. Synthesis-tackling 
the problem of low yield and yield instability of winter cereals in the Mediterranean areas of West Asia, North Africa and Southern Europe. PP. 365-373. In J.P. Srivastana, E. Porceddu, E. Acevedo and S. Varma (eds.). Drought Tolerance in Winter Cereals. Proceedings of an international workshop 27-31 Oct. 1985, Capri, Italy.

Sedgley R. H. 1991. An appraisal of the Donald ideotype after 21 years. Field Crops Res., 26: 221-226.

Seifi A., Visser R. G. F. and Bai Y. 2013. How to effectively deploy plant resistances to pests and pathogens in crop breeding. Euphytica, 190: 321-334.

Shade R. E., Schroeder H. E., Pueyo J. J., Tabe L. M., Murdock L. L., Higgins T. J. V. and Chrispeels M. J. 1994. Transgenic pea seeds expressing the aamylase inhibitor of the common bean are resistant to bruchid beetles. Biotechnology, 12: 793-796.

Shaheen F. A., Khaliq A. and Aslam M. 2006. Resistance of chickpea (Cicer arietinum L) cultivars against pulse beetles. Pak. J. Bot., 38: 1224-1244.

Sharma H. C., Pampapathy G., Lanka S. K. and RidsdillSmith T. J. 2005. Antibiosis mechanism of resistance to pod borer, Helicoverpa armigera in wild relatives of chickpea. Euphytica, 142: 107-117.

Sharma K. D. and Muehlbauer F. J. 2007. Fusarium wilt of chickpea: physiological specialization, genetics of resistance and resistance gene tagging. Euphytica, 157: 1-14.

Singh B. D. 2002. Plant Breeding: Principles and Methods; Kalyani Publishers: New Delhi, India.

Smith E. L. 1987. A review of plant breeding strategies for rainfed areas. In: Drought Tolerance in Winter Cereals, pp. 79-88, (Srivastana, J.P., Porceddu, E., Acevedo, E. and Varma, S., eds). Proceedings of an international workshop 27-31 Oct. 1985, Capri, Italy.

Somta P., Talekar N. S. and Srinives P. 2006. Characterization of Callosobruchus chinensis (L.) resistance in Vigna umbellata (Thunb.) Ohwi \& Ohashi. J. Stored Prod. Res., 42: 313-327.

Somta P., Ammaranan C., Ooi P. A. C. and Srinives P. 2007. Inheritance of seed resistance of bruchids in cultivated mungbean (Vigna radiate L. Wilezek). Euphytica, 155: 47-55.

Somta P., Kaga A., Tomooka N., Isemura T., Vaughan D. A. and Srivines P. 2008. Mapping of quantitative trait loci for a new source of resistance to bruchids in the wild species Vigna nepalens Tateishi \& Maxted (Vigna subgenus Ceratotropis). Theor. Appl. Genet., 117: 621-628.

Tan S. and Bowe S. J. 2009. Developing herbicide-tolerant crops from mutations. Page(s) 315 in Induced Plant Mutations in the Genomics Era (Shu QY, ed.). Food and Agriculture Organization of the United Nations, Rome, Italy.
Tomooka N., Kashiwaba K., Vaugham D. A., Ishimoto M. and Egawa Y. 2000. The effectiveness of evaluating wild species: Searching for sources of resistance to bruchid beetles in the genus Vigna subgenus Ceratotropis. Euphytica, 115: 27-41.

Tullu A., Kaiser W. J., Kraft J. M. and Muehlbauer F. J. 1999. A second gene for resistance to race 4 of Fusarium wilt in chickpea and linkage with a RAPD marker. Euphytica, 109: 43-50.

Udupa S. M. and Baum M. 2003. Genetic dissection of pathotype specific resistance to ascochyta blight resistance in chickpea (Cicer arietinum L.) using microsatellite markers. Theor. Appl. Genet., 106: 1196-1202.

Upadhyaya H. D., Dwivedi S. L., Baum M., Varshney R. K., Udupa S. M., Gowda C. L. L., Hoisington D. and Singh S. 2008. Genetic structure, diversity, and allelic richness in composite collection and reference set in chickpea (Cicer arietinum L.). BMC Plant Biology, 8: 6-12.

Villegas-Ferna'ndez A. M., Sillero J. C. and Rubiales D. 2011. Screening faba bean for chocolate spot resistance: evaluation methods and effects of age of host tissue and temperature. Eur. J. Plant Pathol., 132: 443-453.

Wallace D. H. and Yan W. 1998. Plant breeding and wholesystem crop physiology. University Press, Cambridge, UK.

Woldeyesus S. and Chilot Y. 2002. Participatory client orientation of research in low-input cropping systems of Ethiopia: a view point. In: Gemechu K., Yohannes G., Kiflu B., Chilot Y., Asgelil D. (eds.). Towards farmers' participatory research: attempts and achievements in the central highlands of Ethiopia. Proceedings of client-oriented research evaluation workshop, 16-18 Oct 2001, Holetta Agricultural Research Center, Holetta, Ethiopia, pp 27-43.

Wricke G. and Weber W. E. 1986. Quantitative Genetics and Selection in Plant breeding. Walter de Gruter, Berlin.

Yadav S. S., Kumar J., Yadav S. K., Singh S., Yadav V. S., Turner N. C. and Redden R. 2006. Evaluation of Helicoverpa and drought resistance in Desi and Kabuli chickpea. Plant Genetic Resources, 4: 198203.

Zhao G., Wang J., Han Y., Teng W., Sun G. and Li W. 2008. Identification of QTL underlying the resistance of soybean to pod borer, Leguminivora glycinivorella (Mats.) obraztsov, and correlations with plant, pod and seed traits. Euphytica, 164: 275-282.

Zhu J. 1996. Analysis methods for seed models with genotype $x$ environment interactions. Acta Genetica Sinica, 23: 56-68. 